\title{
Predicting Milk Yield in Sheep Used for Dairying in Australia
}

\author{
A. D. Morrissey, A. W. N. Cameron, D. J. Caddy, and A. J. Tilbrook ${ }^{1}$ \\ Department of Physiology, Monash University, Clayton, Victoria, 3800, Australia
}

\begin{abstract}
It is necessary to identify traits that are simple to measure and correlated with milk yield to select ewes for dairying from existing populations of sheep in Australia. We studied 217 primiparous and 113 multiparous (second parity, $\mathrm{n}=51$; third parity, $\mathrm{n}=40$; and fourth parity, $n=22$ ) East Friesian crossbred ewes, for 2 consecutive lactations, that were milked by machine following a period of suckling (24 to $28 \mathrm{~d}$ ). We measured lamb growth, milk production, milk yield, and residual milk during early lactation ( $<\mathrm{d} 60$ of lactation) to test whether milk production during the suckling period or the growth rate of the lamb predicts milk yield. Milk production at weaning, or the amount of residual milk, or both, predict milk yield within lactations. These measures also predict milk yield between lactations. Lambs were weighed at birth and weaning and milk production in ewes was measured using a 4-h milk production test at $\mathrm{d} 5$ of lactation and at weaning. Following weaning, ewes were milked twice daily and milk yield was recorded weekly for $8 \mathrm{wk}$ and once a month thereafter. Milk production (using a 16 -h milk production test) and residual milk were measured at weaning, and again 1 wk and 4 wk later. Milk yield to $120 \mathrm{~d}$ was correlated $\left(\mathrm{r}^{2}=0.39\right)$ between lactations, and 120-d milk yield (primiparous $82.7 \pm 2.0 \mathrm{~L}$; multiparous $107.1 \pm 4.2 \mathrm{~L}$; second lactation $146 \pm 3.7 \mathrm{~L}$ ) can be predicted after 4 wk of machine milking using a single measurement of either daily milk yield (primiparous $770 \pm 25 \mathrm{~mL} / \mathrm{d}$; multiparous $940 \pm 44 \mathrm{~mL} / \mathrm{d}$; second lactation 1,372 \pm $46 \mathrm{~mL} / \mathrm{d}, \mathrm{r}^{2}=0.60$ to 0.65 ) or daily milk production (primiparous $1,197 \pm 27 \mathrm{~mL} / \mathrm{d}$; multiparous $1,396 \pm 62$ $\mathrm{mL} / \mathrm{d}$; second lactation $1,707 \pm 45 \mathrm{~mL} / \mathrm{d}, \mathrm{r}^{2}=0.50$ to 0.53). Residual milk in primiparous ewes (38\%) and multiparous ewes (34\%) was high $(292 \pm 11$ and $321 \pm$ $20 \mathrm{~mL}$, respectively) in the first lactation, but lower $(17 \%)$ in the second lactation $(238 \pm 17 \mathrm{~mL})$. Residual milk and 120-d milk yield were not correlated in either lactation and we suggest that the transfer of milk from
\end{abstract}

Received May 3, 2007.

Accepted July 5, 2007.

${ }^{1}$ Corresponding author: alan.tilbrook@med.monash.edu.au the alveoli to the cistern between each milking may be an important mechanism that maintains milk yield in these ewes.

Key words: dairy ewe, milk yield, residual milk, repeatability

\section{INTRODUCTION}

The selection of dairy ewes is conducted using repeated measurements of important traits such as milk yield. The coefficient of determination $\left(\mathrm{r}^{2}\right)$ is an important statistic in animal production because it is a measure of repeatability and represents the theoretical upper limit to heritability (Warwick and Legates, 1979).

High-yielding dairy ewes produce relatively large amounts of milk compared with the requirement of the lamb (McKusick et al., 2001) and they release this milk in response to milking by machine rather than suckling by the lamb (Labussiere, 1988; Marnet and Negrao, 2000; McKusick et al., 2001). High-yielding dairy ewes are capable of storing milk for up to $16 \mathrm{~h}$ between milking (Labussiere, 1988) and they persist in lactating for 6 mo or more (Barillet, 1997; McKusick et al., 2001). Furthermore, high-yielding dairy ewes are capable of maintaining high yields and persistent lactations following an extended period of exclusive suckling before machine milking (Labussiere, 1988; Barillet, 1997; McKusick et al., 2001).

The sheep dairy industry in Australia relies on lowyielding crossbred ewes with a low persistency of lactation compared with countries with established sheep dairy industries (Lindsay and Skerritt, 2003). In Australia, primiparous East Friesian $\times$ Merino ewes have greater milk yields $(107 \pm 5 \mathrm{~L})$ and more persistent lactations (128.8 $\pm 10.9 \mathrm{~d})$ compared with other combinations of crossbred ewes used for prime lamb production (Morgan et al., 2006); however, these ewes may not possess some or all of the aforementioned characteristics of high-yielding dairy ewes. It is necessary to identify traits that are simple to measure and correlate with milk yield when ewes are milked by machine to select dairy ewes from existing populations of sheep in Australia, whether crossbred with the East Friesian or not. 
According to traditional management practices, dairy ewes must be capable of suckling lambs for the first 4 wk of lactation and maintaining high levels of milk production when they are milked exclusively by machine (Barillet, 1997; McKusick et al., 2001). Lamb growth and ewe milk production are correlated during early lactation (Snowder and Glimp, 1991), and traits such as the growth rate of the lamb or rate of milk production during the suckling period may predict milk yield when nondairy ewes are milked by machine.

A lack of milk ejection may explain the low yields of Australian crossbred ewes used for dairying. For example, large amounts of milk (residual milk) are retained in the udders of dairy cows that do not eject their milk during machine milking, and it is possible to predict the length of lactation in cows using measurements of residual milk (Murugaiyah et al., 2001). Measurement of residual milk in ewes may indicate milk ejection and may explain sufficient variability in milk yield to permit selection of nondairy ewes best suited to milking by machine.

We studied East Friesian crossbred ewes (for 2 consecutive lactations) that were milked by machine following a period of suckling ( $\sim 28 \mathrm{~d})$ to test the following hypotheses. First, milk production during the suckling period or the growth rate of the lamb predicts milk yield. Second, milk production at weaning, the amount of residual milk, or both, predict milk yield within lactations. Third, these measures predict milk yield between lactations.

\section{MATERIALS AND METHODS}

\section{Animals}

Two consecutive lactations of 217 primiparous and 113 multiparous ewes (second parity, $\mathrm{n}=51$; third parity, $\mathrm{n}=40$; and fourth parity, $\mathrm{n}=22$ ) were studied as part of a self-replacing flock of crossbred ewes $(50 \%$ East Friesian, and 50\% predominantly Polled Dorset or White Suffolk) used in a commercial dairy (Meredith Dairy, Victoria, Australia). The ewes were part of a commercial flock that was milked year round and managed to lamb every $9 \mathrm{mo}$, and consequently, the ewes lambed first in spring and then in the following winter. At the beginning of the first lactation, primiparous ewes gave birth to 118 single lambs (63 female and 55 male lambs) and 158 twin lambs (84 female and 74 male lambs), whereas multiparous ewes gave birth to 50 single lambs (24 female and 26 male lambs) and 110 twin lambs (64 female and 46 male lambs). By the second lactation, all ewes had lambed once and parity was removed as a between-subjects factor. At the beginning of the second lactation, ewes gave birth to 63 single lambs (40 female and 23 male lambs) and 138 twin lambs ( 54 female and 84 male lambs). On both occasions, ewes suckled their lambs for 24 to $28 \mathrm{~d}$ before the lambs were weaned and the ewes were milked exclusively by machine until daily milk yield fell below 500 $\mathrm{mL}$ or ewes were $>3$ mo pregnant. Ewes were milked at 0600 and $1500 \mathrm{~h}$ each day in a 10-aside herringbone dairy with the milking machines set to provide 160 pulsations per minute in a 60:40 ratio with a vacuum of $38 \mathrm{kPa}$. Ewes were kept outdoors day and night and grazed pastures of perennial ryegrass and subterranean clover, or Lucerne, during late pregnancy and early lactation until the pasture quality declined. Thereafter, ewes were fed an ad libitum mixture of vetch hay, silage, canola meal, and barley (designed to be $16 \% \mathrm{CP}$ ). At each milking, ewes received an additional $250 \mathrm{~g}$ of barley.

To maintain a 9-mo interval between lambing, estrous cycles were synchronized at approximately 90 to $120 \mathrm{~d}$ postpartum, whether or not ewes were lactating. Ewes were treated for 10 to $12 \mathrm{~d}$ with sponges impregnated with progestogen (Ovagest Intravaginal Sponge, Bioniche Animal Health Australasia Pty. Ltd., Armidale, New South Wales, Australia) and given an i.m. injection of 600 IU of pregnant mare serum gonadotropin (Pregnecol injection, Novartis Animal Health Australasia Pty. Ltd., Pendle Hill, New South Wales, Australia) at sponge withdrawal. Ewes were mated to rams and pregnancy was diagnosed by ultrasound $40 \mathrm{~d}$ later.

All animal procedures were conducted with prior institutional ethical approval under the requirements of the Australian Prevention of Cruelty to Animals Act (1986) and the National Health and Medical Research Council/Commonwealth Scientific and Industrial Research Organization/Australian Animal Commission Code of Practice for the Care and Use of Animals for Scientific Purposes (2004).

\section{Experimental Design}

The following measurements were made during early lactation ( $<\mathrm{d} 60$ of lactation) to compare lactations of primiparous and multiparous ewes: a) milk production and growth rates of the lambs measured during the suckling period, b) milk yield, milk production, and residual milk measured during the first 4 wk of machine milking. Thereafter, daily milk yield was measured at regular intervals until milking was discontinued.

Measurements During the Suckling Period. Growth rate (g/d) was determined by weighing lambs within $24 \mathrm{~h}$ of parturition and at weaning 24 to $28 \mathrm{~d}$ later. Milk production $(\mathrm{mL} / \mathrm{d})$ during the suckling period was measured at $5 \mathrm{~d}$ and 24 to $28 \mathrm{~d}$ postpartum using a 4-h milk production test (McCance, 1959). Ewes were separated from their lambs, given an i.m. injection 
of 5 IU of oxytocin (Ilium Syntocin, Troy Laboratories Pty. Ltd., Smithfield, New South Wales, Australia), and milked immediately with a milking machine. A second i.m. injection of $5 \mathrm{IU}$ of oxytocin was given and milking was repeated to ensure that as much milk as possible was removed from the udder. After $4 \mathrm{~h}$, ewes were milked again following an i.m. injection of 5 IU of oxytocin. The volume of milk was recorded (within $50 \mathrm{~mL}$ ) using milk meters fitted with goat nozzles (Waikato MK5, Waikato, New Zealand) and used to calculate daily milk production. A dose of 1 to $10 \mathrm{IU}$ of oxytocin (i.m.) was sufficient to ensure milk ejection in ewes (Bencini, 1995).

Measurements During the Milking-Only Period. Milk yield (L) for the milking-only period was calculated according to the method of Pollott and Gootwine (2001) using the simplified method of recording milking yield from a single test at monthly intervals (ICAR, 1992). Milk volumes were recorded at the morning milking (without administering oxytocin) at weekly intervals for the first 8 wk of machine milking, and thereafter once a month until daily production fell below $500 \mathrm{~mL} /$ d. Estimates of milk yield to $120 \mathrm{~d}$ (El Saied et al., 1998) were used to standardize the length of lactation and to avoid potential biases due to the effect of pregnancy on lactation.

Milk production $(\mathrm{mL} / \mathrm{d})$ and residual milk $(\mathrm{mL})$ were measured at the morning milking following weaning, $1 \mathrm{wk}$ later, and at $4 \mathrm{wk}$ after weaning. Milk production was measured using an interval of $16 \mathrm{~h}$ between milking to measure the ability of each ewe to store milk and maintain milk secretion. Residual milk was measured using the method of Murugaiyah et al. (2001). At the evening milking before this test, ewes were given 2 i.m. injections of $5 \mathrm{IU}$ of oxytocin to remove as much milk as possible from the udder. The next morning, ewes were milked and the volume of milk recorded. Ewes were then given an i.m. injection of 5 IU of oxytocin and milked a second time. Another injection of oxytocin was given and ewes were milked a third time, and the volume of residual milk was recorded.

\section{Statistical Analysis}

Data from these experiments were statistically analyzed using repeated-measures ANOVA and by correlation and regression. Parity (primiparous or multiparous), offspring number (single or twin), and sex of the lamb (female or male) were used as between-subjects factors in each repeated-measures ANOVA. In separate analyses, time since weaning (measured in weeks), and either daily milk yield, milk production estimated by $16 \mathrm{~h}$ of milk accumulation, and residual milk were used as the within-subjects factors in the repeated-measures

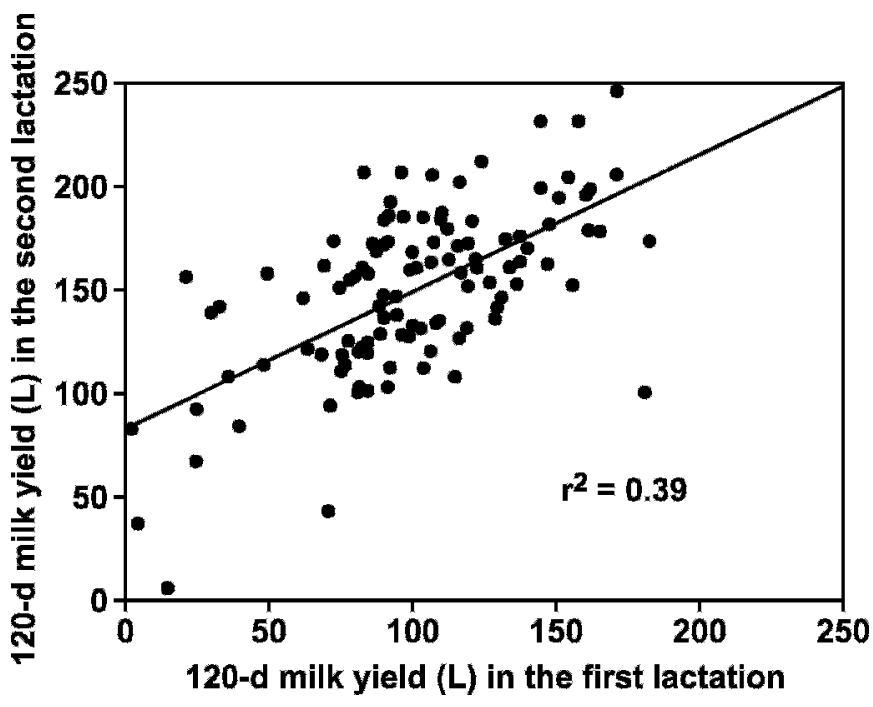

Figure 1. Correlation $\left(\mathrm{r}^{2}=0.39, P \leq 0.001, \mathrm{n}=113\right)$ between 120 $\mathrm{d}$ milk yield ( $\mathrm{L}$ ) during the first lactation and 120 -d milk yield during the second lactation.

ANOVA. The error terms considered when performing each ANOVA were daily milk yield, milk production (16 h), and residual milk, respectively. Correlation analyses were used to examine relationships between lamb growth rates, estimates of milk production, residual milk and milk yield. A priori decisions to exclude ewes (first lactation $\mathrm{n}=74$; second lactation $\mathrm{n}=93$ ) from analysis were made if any of the following conditions were met: ewes bearing triplets, mortality during the suckling period, lameness, involution of one udder half, injuries to the teats due to biting, or clinical mastitis. Homogeneity of variance was assessed for each set of data using Levine's test of equality of error variances and no transformations were applied. Post hoc comparisons were made where appropriate using least significant differences. Data are presented as the mean \pm SEM and results are considered significant when $P<0.05$.

\section{RESULTS}

\section{Correlations with 120-d Milk Yield}

The coefficient of determination $\left(\mathrm{r}^{2}\right)$ for 120 -d milk yield between consecutive lactations is $0.39(P \leq 0.001$, $\mathrm{n}=113$; Figure 1 ). Daily milk yield after $4 \mathrm{wk}$ of machine milking explained $>60 \%$ of the variability in 120 $\mathrm{d}$ milk yield within lactations $\left(\mathrm{r}^{2}=0.65, P=0.001, \mathrm{n}=\right.$ 243 and $\mathrm{r}^{2}=0.60, P=0.001, \mathrm{n}=132$, respectively), but measurements of daily milk yield after $4 \mathrm{wk}$ of machine milking were lowly correlated between lactations $\left(\mathrm{r}^{2}=\right.$ $0.08, P=0.005, \mathrm{n}=104)$. Similarly, daily milk production, estimated from $16 \mathrm{~h}$ of milk accumulation, after 
4 wk of machine milking, explained $>50 \%$ of the variability in 120-d milk yield within lactations $\left(\mathrm{r}^{2}=0.50\right.$, $\mathrm{n}=243$ and $\mathrm{r}^{2}=0.53, \mathrm{n}=115$, respectively), but measurements of daily milk production after 4 wk of machine milking were lowly correlated between lactations $\left(\mathrm{r}^{2}=0.08, P=0.005, \mathrm{n}=99\right)$. Daily milk yield or milk production, measured during the first lactation at $4 \mathrm{wk}$ after the commencement of machine milking, were low predictors of 120-d milk yield in the subsequent lactation $\left(\mathrm{r}^{2}=0.17, P \leq 0.001, \mathrm{n}=112\right.$, and $\mathrm{r}^{2}=0.11, P \leq$ $0.001, \mathrm{n}=111$, respectively). Milk production at weaning measured using either a 4 -h milk production test $\left(\mathrm{r}^{2}=0.03, P=0.013, \mathrm{n}=244\right)$ or a $16-\mathrm{h}$ milk production test $\left(\mathrm{r}^{2}=0.07, P \leq 0.001, \mathrm{n}=255\right)$ explained almost none of the variability in $120-\mathrm{d}$ milk yield. Residual milk at weaning explained almost none of the variability in 120-d milk yield in either lactation $\left(\mathrm{r}^{2}=0.01\right.$, $P=0.142, \mathrm{n}=255$, and $\mathrm{r}^{2}=0.01, P=0.201, \mathrm{n}=115$, respectively). The growth rate of the lamb explained almost none of the variability in 120 -d milk yield $\left(\mathrm{r}^{2} \leq\right.$ 0.08 , in both lactations $P=0.062$ ).

\section{Production Data for East Friesian Crossbred Ewes}

During the first lactation, the machine-milking period was similar for primiparous $(\mathrm{n}=180)$ and multiparous $(\mathrm{n}=76)$ ewes $(130.2 \pm 3.7$ and $131.8 \pm 4.5 \mathrm{~d}$, respectively), and estimates of total milk yield during that period were $109.6 \pm 4.0$ and $126.8 \pm 5.7 \mathrm{~L}$ for primiparous and multiparous ewes, respectively $(P=0.016)$. Milk yield to $120 \mathrm{~d}$ was greater in multiparous ewes $(107.1 \pm 4.2 \mathrm{~L})$ than in primiparous ewes $(82.7 \pm 2.8 \mathrm{~L})$ during the first lactation of this study. In comparison, ewes $(n=132)$ were milked for $160.1 \pm 4.0 \mathrm{~d}$ in the second lactation and the total milk yield was $192.9 \pm$ $6.9 \mathrm{~L}$, and the 120-d milk yield for the second lactation was $146.4 \pm 3.7 \mathrm{~L}$. The coefficient of variation of total milk yield was $49.2 \%$ for primiparous ewes and $41.2 \%$ for multiparous ewes. After 4 wk of machine milking, daily milk yield $(770 \pm 25 \mathrm{~mL} / \mathrm{d})$ and daily milk production $(1,197 \pm 29 \mathrm{~mL} / \mathrm{d})$ in primiparous ewes was lower $(P<0.05)$ than daily milk yield $(940 \pm 44 \mathrm{~mL} / \mathrm{d})$ and daily milk production $(1,396 \pm 62 \mathrm{~mL} / \mathrm{d})$ in multiparous ewes during the first lactation. In comparison, daily milk yield $(1,372 \pm 46 \mathrm{~mL} / \mathrm{d})$ and daily milk production $(1,707 \pm 45 \mathrm{~mL} / \mathrm{d})$ were greater after $4 \mathrm{wk}$ of machine milking during the second lactation. Residual milk in primiparous ewes $(292 \pm 11 \mathrm{~mL})$ was similar to multiparous ewes $(321 \pm 20 \mathrm{~mL})$ in the first lactation. Residual milk (238 $\pm 17 \mathrm{~mL}$ ) was lower during the second lactation. The growth rate of lambs (combined data for single and twin lambs) born to primiparous ewes (0.308 \pm $0.005 \mathrm{~kg} / \mathrm{d}$ ) was similar to the growth rate of lambs born to multiparous ewes $(0.320 \pm 0.010 \mathrm{~kg} / \mathrm{d})$, and in the second lactation, the mean growth rate of lambs was $0.310 \pm 0.05 \mathrm{~kg} / \mathrm{d}$.

\section{Effects of Parity and Litter Size on Lamb Growth, Daily Milk Yield, Daily Milk Production, and Residual Milk}

The size of the litter (single or twin lambs) affected the rate of growth of the lamb in the first lactation $\left(\mathrm{F}_{(1}\right.$, $372)=72.260, P \leq 0.001)$ and second lactation $\left(\mathrm{F}_{(1,197)}=\right.$ $37.462, P \leq 0.001)$ and accounted for more of the variation in lamb growth in both lactations than any other effect. The growth rate of the lamb was affected by the parity of the ewe $\left(\mathrm{F}_{(1,372)}=4.701, P=0.031\right)$, but not the sex of the lamb $\left(\mathrm{F}_{(1,372)}=1.539, P=0.216\right)$ in the first lactation. For primiparous ewes, the growth rate for single lambs $(0.351 \pm 0.003 \mathrm{~kg} / \mathrm{d})$ was greater than for twin lambs $(0.274 \pm 0.002 \mathrm{~kg} / \mathrm{d})$. For multiparous ewes, the growth rate for single lambs $(0.370 \pm 0.014$ $\mathrm{kg} / \mathrm{d})$ was greater than for twin lambs $(0.295 \pm 0.008$ $\mathrm{kg} / \mathrm{d})$. There were differences in the growth rates due to the sex of the lamb $\left(\mathrm{F}_{(1,197)}=7.257, P=0.008\right)$ during the second lactation, after removing parity as a between-subjects factor. Single male lambs grew faster than single female lambs $(0.363 \pm 0.008$ and $0.343 \pm$ $0.010 \mathrm{~kg} / \mathrm{d}$ for male and female, respectively) and twin male lambs grew faster than twin female lambs $(0.306$ \pm 0.007 and $0.268 \pm 0.009 \mathrm{~kg} / \mathrm{d}$ for male and female, respectively).

The parity of the ewe in the first lactation affected daily milk yield during the first $8 \mathrm{wk}$ of machine milking $\left(\mathrm{F}_{(8,1896)}=4.347, P \leq 0.001\right.$; Figure 2$)$, daily milk production during the first $4 \mathrm{wk}$ of machine milking $\left(\mathrm{F}_{(2,482)}=\right.$ $6.651, P=0.001$; Figure 3), and residual milk during the first $4 \mathrm{wk}$ of machine milking $\left(\mathrm{F}_{(2,482)}=3.837, P=\right.$ 0.022 ; Figure 4$)$. The size of the litter did not affect daily milk yield $\left(\mathrm{F}_{(16,1896)}=1.102, P=0.346\right)$, daily milk production $\left(\mathrm{F}_{(4,482)}=1.083, P=0.364\right)$, or residual milk $\left(\mathrm{F}_{(16,482)}=1.001, P=0.401\right)$. In comparison, during the second lactation, the size of the litter did not affect daily milk yield $\left(\mathrm{F}_{(8,1040)}=1.352, P=0.214\right)$; however, both daily milk production $\left(\mathrm{F}_{(2,224)}=8.182, P \leq 0.001\right)$ and residual milk $\left(\mathrm{F}_{(2,224)}=7.886, P \leq 0.001\right)$ were affected by the size of the litter.

Time affected daily milk yield $\left[\left(\mathrm{F}_{(8,1896)}=38.148, P\right.\right.$ $\leq 0.001)$ and $\left.\left(\mathrm{F}_{(8,1040)}=5.711, P \leq 0.001\right)\right]$, daily milk production $\left[\left(\mathrm{F}_{(2,482)}=230.042, P \leq 0.001\right)\right.$ and $\left(\mathrm{F}_{(2,224)}=\right.$ 91.286, $P \leq 0.001)]$, and residual milk $\left[\left(\mathrm{F}_{(2,482)}=\right.\right.$ 336.104, $P \leq 0.001)$ and $\left.\left(\mathrm{F}_{(2,224)}=164.001, P \leq 0.001\right)\right]$, for the first and second lactations, respectively. In every case, time accounted for more of the variation in these measurements than either the parity of the ewe or litter size. There were no consistent changes in daily milk yield during the first $8 \mathrm{wk}$ of machine milking (Figure 


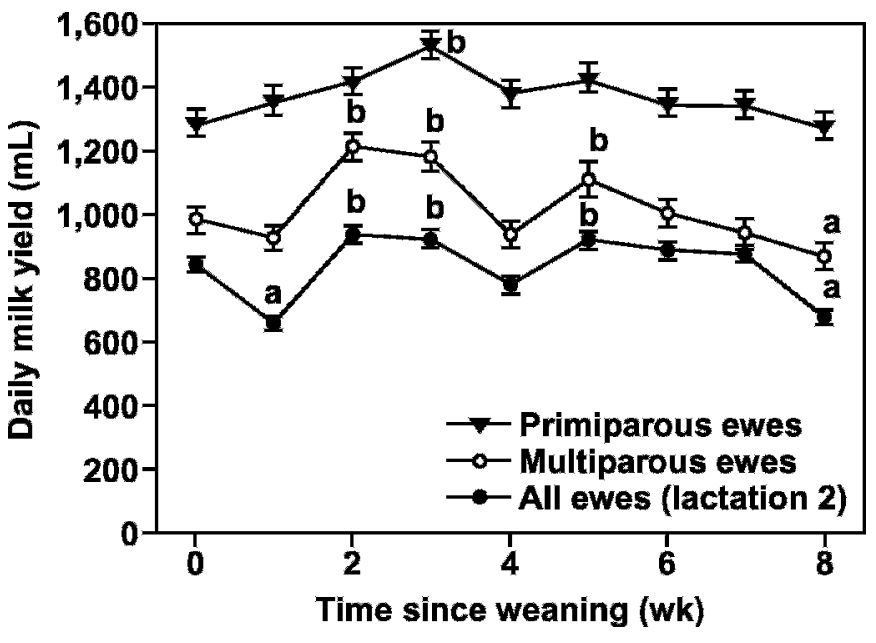

Figure 2. Mean $( \pm$ SEM) daily milk yield $(\mathrm{mL})$ in primiparous and multiparous ewes measured at weekly intervals during the first 8 wk of machine milking. Daily milk yield was affected by parity $(P$ $\leq 0.001)$. Mean $( \pm$ SEM) daily milk yield $(\mathrm{mL})$ for all ewes included in the second lactation measured at weekly intervals over the first $8 \mathrm{wk}$ of machine milking. Within each lactation, time affected daily milk yield $(P \leq 0.001)$, and differences in daily milk yield from weaning are represented by different letters: ${ }^{a}$ lower milk yield, ${ }^{b}$ higher milk yield, $P<0.05$.

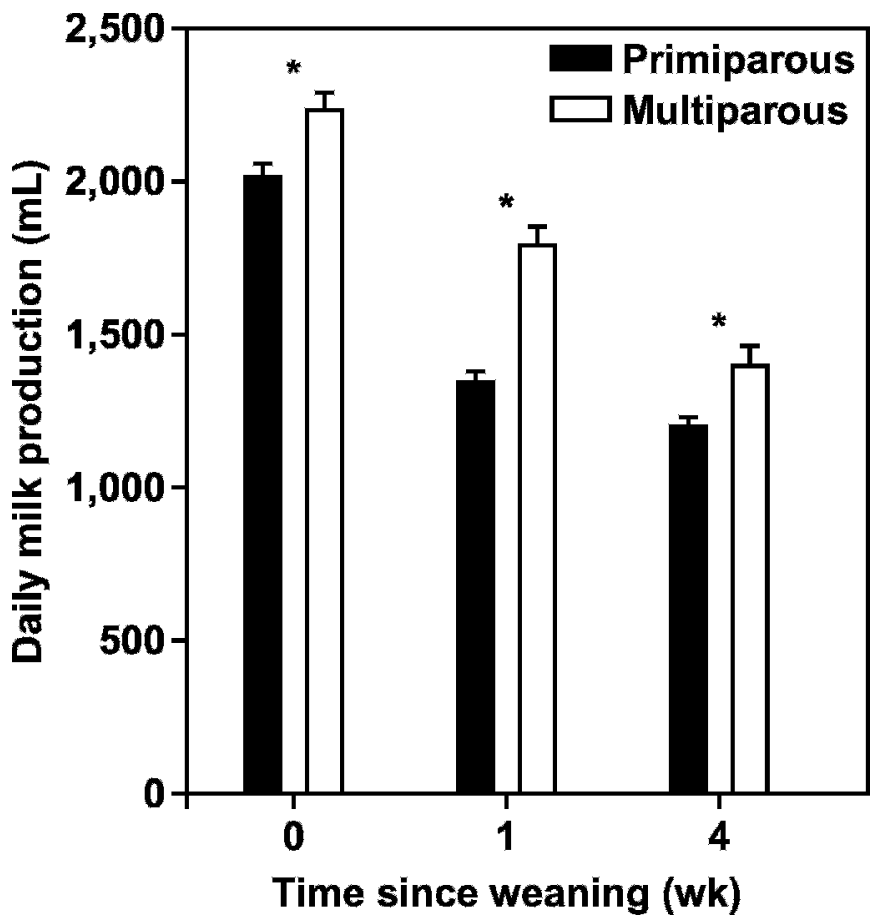

Figure 3. Mean $( \pm \mathrm{SEM})$ daily milk production $(\mathrm{mL})$ in primiparous and multiparous ewes measured during the first $4 \mathrm{wk}$ of machine milking (at weaning, after $1 \mathrm{wk}$, and after $4 \mathrm{wk}$ ). Daily milk production was affected by time $(P \leq 0.001)$ and parity $(P \leq 0.001)$. Differences between parity at each time point are represented by $*(P<0.05)$.

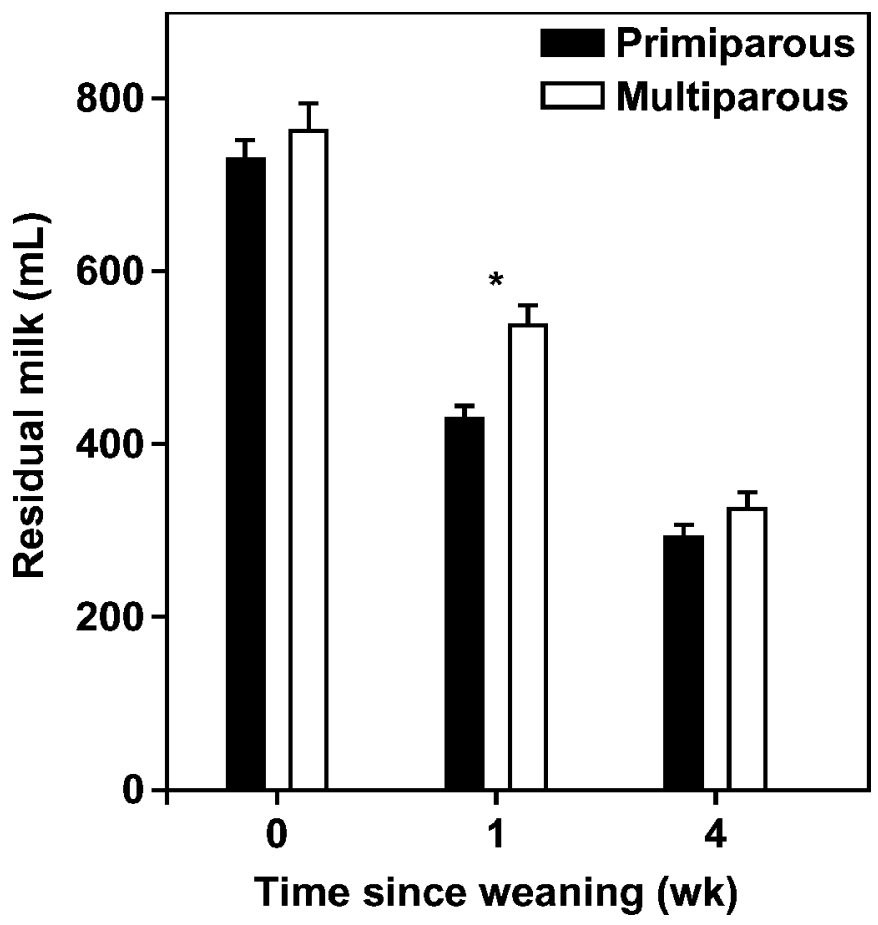

Figure 4. Mean $( \pm$ SEM) residual milk $(\mathrm{mL})$ in primiparous and multiparous ewes measured during the first $4 \mathrm{wk}$ of machine milking (at weaning, after $1 \mathrm{wk}$, and after $4 \mathrm{wk}$ ). Residual milk was affected by time $(P \leq 0.001)$ and parity $(P \leq 0.001)$. Differences between parity at each time point are represented by $*(P<0.05)$.

2); however, both daily milk production (Figure 3) and residual milk (Figure 4) decreased during the first 4 wh of machine milking.

\section{DISCUSSION}

Milk yield to $120 \mathrm{~d}$ explained $39 \%$ of the variation in milk yield between lactations and suggested that the repeatability of milk yield is sufficient to permit selection of ewes based on 120-d milk yield. The relationship was similar for primiparous and multiparous ewes and implied that selection could be based on first lactations. Milk yield to $120 \mathrm{~d}$ can be predicted early in lactation by daily milk yield after 4 wk of machine milking. Measurement of milk production (using a 16 -h milk production test) after 4 wk of machine milking predicted 120 $\mathrm{d}$ milk yield. These measurements may allow producers to screen ewes to eliminate low-yielding ewes from the milking flock.

Lamb growth during the suckling period did not predict 120-d milk yield, which suggests that this trait cannot be used to identify ewes that would be suited to machine milking. We found no correlation between lamb growth and milk production during the suckling period, and our data indicate, as others have suggested 
(McKusick et al., 2001), that dairy ewes produce quantities of milk in excess of the requirements of the lamb. A further implication of excessive milk production during the suckling period is that alternate management of these ewes, either mixed management or early weaning of lambs, should be considered (McKusick et al., 2001).

The rates of milk production at weaning were not correlated to 120 -d milk yield and were due to the rapid declines in milk production over the first week of machine milking, a finding that is consistent with the 30 to $50 \%$ decrease in milk production reported by others (Labussiere, 1988; McKusick et al., 2001). This may explain why the galactopoietic effects on milk production of ewes suckling single and twin lambs disappeared after 4 wk of machine milking. Milk production after $16 \mathrm{~h}$ of milk accumulation was correlated with milk yield after $4 \mathrm{wk}$ of machine milking and we suggest that the rate of milk production measured at 16 -h intervals reflects the ability of ewes to store milk between each milking.

Measurements of residual milk were uninformative because we found no relationship between residual milk and 120-d milk yield. In addition, the normal distribution of residual milk eliminated the possibility of identifying ewes that do not eject their milk. Transfer of milk away from the alveoli to the cistern after milking (Marnet and McKusick, 2001) may explain the lack of relationship between residual milk and 120-d milk yield; however, the mechanisms that allow this transfer remain unclear. Temporary inhibition of milk ejection for 1 to $5 \mathrm{~d}$ occurs as dairy sheep (Marnet and Negrao, 2000; Negrao and Marnet, 2003) and dairy cows (Bruckmaier, 2005) overcome the imposition of varied and simultaneous acute stressors on entry to the dairy. The reduction in residual milk over the first $4 \mathrm{wk}$ of machine milking reflects changes in milk production.

\section{CONCLUSIONS}

The most important finding is that 120 -d milk yield between lactations is correlated and repeatable in ewes that are managed to lamb every 9 mo and are milked at different times of the year. Milk yield to $120 \mathrm{~d}$ can be predicted after 4 wk of machine milking using a single measurement of either daily milk yield or daily milk production. Residual milk in primiparous and multiparous ewes was high in the first lactation, but lower in the second lactation. Residual milk and 120-d milk yield did not correlate in either lactation and we suggest that the transfer of milk from the alveoli to the cistern between each milking may be an important mechanism that maintains milk yield in these ewes.

\section{ACKNOWLEDGMENTS}

We thank the staff at Meredith Dairy for their assistance throughout this study. This study was supported by a Rural Industries Research and Development Corporation-New Industries grant.

\section{REFERENCES}

Anonymous. 2004. Australian code of practice for the care and use of animals for scientific purposes. National Health and Medical Research Council, Commonwealth Scientific and Industrial Research Organization, Australian Research Council, and Australian Vice-Chancellor's Committee. 7th ed.

Barillet, F. 1997. Genetics of milk production. Pages 539-564 in The Genetics of Sheep. L. Piper and A. Ruvinsky, ed. CAB International, Cambridge, UK.

Bencini, R. 1995. Use of intramuscular injections of oxytocin to measure milk output in nondairy sheep, and its effects on milk composition. Aust. J. Exp. Agric. 35:563-565.

Bruckmaier, R. M. 2005. Normal and disturbed milk ejection in dairy cows. Domest. Anim. Endocrinol. 29:268-273.

El Saied, U. M., J. A. Carriedo, L. F. De La Fuente, and F. San Primitivo. 1998. Genetic and environmental estimations for testday and standardized milk yield of dairy sheep. Small Rumin. Res. 27:209-215.

ICAR. 1992. International Regulations for Milk Recording in Sheep. Institut de l'Elevage, Paris, France.

Labussiere, J. 1988. Review of physiological and anatomical factors influencing the milking ability of ewes and the organization of milking. Livest. Prod. Sci. 18:253-274.

Lindsay, D. R., and J. Skerritt. 2003. Improved breeding for dairy goats and milking sheep: Guidelines for the development of national breeding plans. Rural Industries and Research Development Corporation publication no 02/150. CanPrint Communications, Fyshwick, Australia.

Marnet, P. G., and B. C. McKusick. 2001. Regulation of milk ejection and milkability in small ruminants. Livest. Prod. Sci. 70:125-133.

Marnet, P. G., and J. A. Negrao. 2000. The effect of a mixed-management system on the release of oxytocin, prolactin, and cortisol in ewes during suckling and machine milking. Reprod. Nutr. Dev. 40:271-281.

McCance, I. 1959. The determination of milk yield in the Merino ewe. Aust. J. Agric. Res. 10:839-853.

McKusick, B. C., D. L. Thomas, and Y. M. Burger. 2001. Effect of weanings on commercial milk production and lamb growth of East Friesian dairy sheep. J. Dairy Sci. 84:1660-1668.

Morgan, J. E., N. M. Fogarty, S. Nielsen, and A. R. Gilmour. 2006. Milk yield and milk composition from grazing non-dairy primiparous crossbred ewes. Aust. J. Agric. Res. 57:377-387.

Murugaiyah, M., P. Ramakrishnan, A. R. Sheikh Omar, C. H. Knight, and C. J. Wilde. 2001. Lactation failure in crossbred Sahiwal Friesian cattle. J. Dairy Res. 68:165-174.

Negrao, J. A., and P. Marnet. 2003. Cortisol, adrenalin, noradrenalin and oxytocin release and milk yield during first milkings in primiparous ewes. Small Rumin. Res. 47:69-75.

Pollott, G. E., and E. Gootwine. 2001. A genetic analysis of complete lactation milk production in improved Awassi sheep. Livest. Prod. Sci. 71:37-47.

Snowder, G. D., and H. A. Glimp. 1991. Influence of breed, number of suckling lambs, and stage of lactation on ewe milk production and lamb growth under range conditions. J. Anim. Sci. 69:923930.

Warwick, E. J., and J. E. Legates. 1979. Breeding and Improvement of Farm Animals. 7th Edition. Tata McGraw-Hill Publishing Company Ltd., New Delhi, India. 